Legal Issues in the Digital Age. 2021. Vol. 2, no. 4

Research article

UDC: 349

DOI: $10.17323 / 2713-2749.2021 .4 .98 .113$

\title{
Legal Basis for Remote Sale of Medicines in the Russian Federation
}

\section{目 Alexander S. Kornienko', 凡目 Nadezhda G. Neretina ${ }^{2}$}

\author{
${ }^{1}$ National Research University Higher School of Economics \\ ${ }^{2}$ Russian Presidential Academy of National Economy and Public Administration \\ 1 akornienko@hse.ru, https://orcid.org/0000-0002-0759-2921 \\ ${ }^{2}$ email: Nadezhdalow@mail.ru, ORCID: 0000-0003-1606-6007
}

\section{囲围 Abstract}

The topic of the article is very relevant, first of all, due to the fact that today the development of the information and telecommunication services market involves almost all areas of people's life in the field of e-commerce. Until April 2020, it was not possible to purchase a medicinal product online on the territory of the Russian Federation due to the lack of a regulatory legal framework regulating such a mechanism. However, at the moment, the relevant legislation has entered into force, regulating in detail the sale of medicines in a remote format. Taking into account the presented circumstances, it seems to us that the issue of studying new legislative acts in the field of remote sale of medicines on the territory of the Russian Federation is largely being updated. The subject of the article is the mechanism of legal regulation of remote sale of medicines in Russia. The purpose of the study is to identify the problems of legal regulation of the process of remote sale of medicines in the Russian Federation at the present stage. This research is based on a combination of groups of classical general scientific methods (induction, deduction, analysis, synthesis) and a number of special methods of scientific cognition applied directly within the framework of legal science (formal legal, comparative legal and others). Within the framework of the presented article, the authors carried out a conceptual analysis of the features of the legal regulation of the sale of medicines using remote technologies, taking into account the latest changes in legislation. The specifics of remote trade in prescription and over-the-counter drugs, as well as the peculiarities of labeling of medicines on the territory of the Russian Federation, are analyzed. As a result of a comprehensive study of current trends in regulatory regulation and justification of possible methods for improving the systems for issuing electronic prescriptions, as well as mandatory labeling of medicines, a conclusion is made 
about the possibility of further development of remote trade in medicines in the Russian Federation.

\section{O-n 国 Keywords}

remote sales, trade, e-commerce, medicines, electronic prescription, prescription and over-the-counter delivery of medicines, regulatory framework, COVID-19, pandemic

For citation: Kornienko A.S., Neretina N.G. Legal Basis for Remote Sale of Medicines in the Russian Federation. Legal Issues in the Digital Age. 2021, no. 4, pp. 98-113. DOI: 10.17323/2713-2749.2021.4.98.113.

\section{Introduction}

The COVID-19 pandemic has dramatically affected all spheres of public life without any exception. Among other things, it has determined the key regulatory trends in various areas during the pandemic and post-pandemic period. The modernization process in the Russian legal institutions included a number of major steps. First of all, the legislation on the sanitary and epidemiological welfare of the population has been urgently amended. It should be noted that these amendments led to the introduction and enforcement of fines for violating a high-alert regime, specifically for walking around town without reasonable grounds. Secondly, the rules regulating remote sales of medicines were modified. While the period before 2020 saw no legislative developments in this area, the acute phase of the coronavirus pandemic necessitated an urgent introduction of online technologies, which would allow to minimize face-to-face contacts and reduce the spread of COVID-19, thus helping to save people's life and health. Thus, introduction of remote sales of pharmaceuticals primarily was discussed at the State Duma level. It was proposed to make an appropriate amendment to the Federal Law providing for the possibility to sell OTC medications online from 1 July 2020 and prescription drugs - from 2022. Furthermore, it was proposed to introduce an additional legal novelty and authorize online sales of other pharmacy goods [Belova O.A., 2021:109]. In this context, it means mostly dietary supplements, medical foods, first-aid products and other medical goods. ${ }^{1}$

${ }^{1}$ Isaev A.K. Remote Pharmaceutical Sales. Available at: https://rg.ru/2019/11/12/ isaev-torgovlia-cherez-internet-sdelaet-lekarstva-bolee-dostupnymi.htm (accessed: 20.11.2021); Vukolova T. Remote Sales of Medicines. Available at: https://zakon.ru/ blog/2020/03/19/distancionnaya_torgovlya_lekarstvami (accessed: 20.11.2021) 
The described trend in the improvement of the established legal practices continued and led to a number of important developments.

This change in the basic paradigm brought about further modification of the legislation: in March 2020 the President signed the Decree regulating general principles of the online trade in pharmaceuticals; in April an appropriate law was adopted (it should be noted that this regulation primarily had a clear delegatory character, i.e. enabling the Government to perform certain activities) [Egorova A.V., 2021: 47]. As was pointed out by T. Vukolova in her article, "following the adoption of the draft after the first reading, the legislative procedure was suspended for unknown reasons". ${ }^{2}$ As a result, the original amendment timeframes were protracted over nearly three years instead of several months. Only some of the basic principles of the online trade in medications were adopted in May.

So, one can see a certain speedup in the process of transition to on online trade in medications: after the respective President's request, the draft considered by the Duma for nearly three years was adopted just within two weeks.

From a brief overview of the processes observed in the Russian legislation and economy, we'll pass on to a more detailed examination of the innovations triggered by the Presidential Decree No 187 "On Retail Trade in Drugs for Medical Use"3.

The above decree served as a basis for other laws adopted two weeks later, namely: Federal Law No 105-FZ "On Amending Article 15.1 of the Federal Law on Information, Information Technologies and Protection of Information and the Federal Law on Circulation of Medicines"4.

Having considered general provisions regulating pharmaceutical trade issues, let us turn to major specific aspects, which have a direct impact on the everyday life of Russian citizens. We'll examine how medical prescriptions are issued, whether the related paperwork can be done online, how OTC medications and prescription drugs are dispensed as well as what

${ }^{2}$ Vukolova T. Remote trade in medications. Available at: https://zakon.ru/blog/ 2020/03/19/distancionnaya_torgovlya_lekarstvami (accessed: 20.11.2021)

3 Presidential decree of March 17, 2020 № 187 "On Retail Trade in Drugs for Medical Use”. Available at: http://publication.pravo.gov.ru/Document/View/0001202003170037 (accessed: 20.11.2021)

${ }^{4}$ Federal Law No 105-FZ "On Amending Article 15.1 of the Federal Law on Information, Information Technologies and Protection of Information and the Federal Law on Circulation of Medicines". Available at: http://publication.pravo.gov.ru/Document/ View/0001202004030060 (accessed: 21.11.2021) 
requirements are imposed on e-commerce businesses in accordance with the Resolution of the Russian Government and other bylaws 5 .

\section{Regulation of Procedures for Issuing Medical Prescriptions}

At present, there are two major procedures for issuing medical prescriptions envisioned by the active legislation of the Russian Federation. A citizen of the Russian Federation can obtain a prescription written on a standard form during his/her visit to a medical institution. Alternatively, one can obtain a medical prescription in an electronic form.

Legal grounds for prescribing medications in the Russian Federation are contained in the Federal Law No. 242-FZ of July 21, 2014 "On Amending Some Legislative Acts of the Russian Federation in as Much as It Concerns the Application of Information Technologies in Healthcare"6.

In accordance with this law, prescriptions for narcotic drugs or psychotropic substances shall be issued on standard official paper forms or - on condition of the patient's (or his/her legal representative's) prior consent - in the form of e-documents with an enhanced encrypted and certified digital signature of the person responsible for issuing the respective prescriptions in a given medical institution [Gorshkova V.M., Streltsov R.S., 2021: 49].

Furthermore, the approach to legal interpretation of the term "prescription" underwent a transformation. Currently, a prescription is understood to be a medical document, which has an established form and contains information about the prescribed pharmaceutical for medical use. It is issued by medical professionals with a view to enable patients to get the necessary medication from a pharmacy. It can be a standard written prescription or an electronic document. In the latter case, prior consent of the patient or his/her legal representative is required. As was noted by L.M. Ibragimova,

${ }^{5}$ Resolution of the Government of the Russian Federation No 697 of May 16, 2020 "On adoption of the Rules for issuing permits for the remote (distance) retail sale of medicines for medical use, as well as implementation of such trade and delivery of such medicines to citizens, and amending certain acts of the Government of the Russian Federation concerning the retail trade in medicines for medical use." Available at: http://publication.pravo.gov. ru/Document/View/0001202005180035 (accessed: 22.11.2021)

${ }^{6}$ Federal Law No. 242-FZ of July 21, 2014 "On Amending Some Legislative Acts of the Russian Federation in as Much as It Concerns the Application of Information Technologies in Healthcare". Available at: http://publication.pravo.gov.ru/Document/ View/0001201707300032 (accessed: 22.11.2021) 
the term is also applicable "to standard paper medication forms containing prescription of pharmaceutical preparations for veterinary use" [Ibragimova L.M., 2021: 935].

The Unified State Healthcare Information System (further on referred to as USHIS) is an important element of the mechanism whereby prescriptions for medications are issued. USHIS contains the data reflected in the federal information systems, data on medical organizations (with the exception of medical organizations subordinate to the Federal Government bodies whose line of responsibilities involves military or equal-status service in accordance with Federal laws); data on medical documentation, which does not allow to determine patients' health condition; statistical data, etc. [Karonsky E.V., 2021: 255].

In the context set by the Federal law, the Ministry of Health of the Russian Federation drafted two ministerial orders, which provide a more detailed description of different prescription formats. ${ }^{7}$

Let us consider major provisions of the regulations issued by the Russian Health Ministry related to prescription of pharmaceutical preparations.

First and foremost, all the information about the medication prescribed (i.e. name, dosage, administration and application techniques, duration of treatment, justification for prescribing a given preparation) should be reflected in the patient's medical records. A prescription is issued either on a special printed medication form or as an electronic document (in the latter case, prior consent of the patient or his/her legal representative is required) [Magomedov A.M., 2020: 61].

Electronic prescriptions for narcotic drugs or psychotropic substances must be signed with an enhanced encrypted and certified digital signature of a physician, paramedic or maternity nurse (provided the above medical staff members have the authority to issue respective prescriptions). ${ }^{8}$

7 Order of the Ministry of Health No 4n of January 14, 2019 "On Approval of Procedure for Prescription of Medications, Prescription Forms, and Procedure for Completion, Registration and Storage thereof". Available at: http://publication.pravo.gov.ru/Document/ View/0001201903270029 (accessed: 22.11.2021); Order of the Ministry of Health No 198n of March 19, 2020 "On temporary procedure for the organization of work of medical organizations for the purpose of implementing measures for prevention and decrease in risks of spread of new coronavirus infection COVID-19". Available at: http://publication.pravo. gov.ru/Document/View/0001202003190038 (accessed: 22.11.2021)

${ }^{8}$ Federal Law № 63-FZ of April 6, 2011 “On Electronic Signature”. Available at: https:// base.garant.ru/12184522/ (accessed: 22.11.2021) 
Furthermore, the ministerial order specifies that electronic prescriptions can be issued on condition that the use of e-prescriptions was approved on this constituent territory by the respective regional authorities.

If a patient is discharged from the hospital following inpatient care, he/ she receives a prescription for further treatment issued upon a decision of the head of the hospital in electronic or paper form (alternatively, the required medications can be given to the patient at discharge for a period of further outpatient treatment not exceeding 5 days $)^{9}$.

The document is drawn in the name of the patient for whom the medication is prescribed. Prescriptions in an electronic form are completed automatically by the information system of the respective constituent entity of the Russian Federation. It is mandatory to document the issuance of each prescription in medical records [Krasilnikov E.F., Nikishin A.F., 2019: 218].

It is prohibited to issue prescriptions in the absence of appropriate medical grounds. Besides, it is absolutely inadmissible to include references to unregistered medications in the prescriptions. A unified set of requirements regulates the procedure for completing all types of prescriptions. Every prescription contains the following information: composition of the pharmaceutical preparation in Latin, dosage, how often and when the medication should be taken (in the morning or in the evening, duration of treatment, compatibility with the diet) [Kugach V.V., Davidovich E.I., 2017: 94]. As far as a time limit on the prescription is concerned, prescriptions of type 148-1/u-88 are valid for fifteen days and prescriptions of type 148-1/u-04(l), for thirty days from the date of issuance. If the prescription validity period is one year, it should bear a "Specialized prescription" mark as well as clear indication of the length of the validity period, and time intervals at which the medication can be dispensed. The obtained prescription is certified with a signature and stamp of the medical professional, and stamp of the medical organization. If a prescription is issued in e-form, it should be certified with enhanced digital signature. Unduly completed prescriptions are deemed invalid ${ }^{10}$.

Thus, it should be noted that the system for issuing prescriptions in electronic form can work only if the regional authorities enact the appropriate legislation. Once they have done so, the authorities of constituent

9 Order of the Ministry of Health and Social Development № 110 of February 12, 2007 "On the procedure for issuing prescriptions for pharmaceutical preparations, medical products, and specialized medical foods”. Available at: https://base.garant.ru/12153254/ (accessed: 22.11.2021)

10 Ibid. 
entities of the Russian Federation are obliged to comply with the requirements set out in the Order of the Russian Health Ministry. However, if the regional authorities abstain from a decision to introduce electronic prescriptions, the above ministerial order is applicable only to the issuance of prescriptions in paper form.

To date implementation of the electronic prescription program is underway only in a few constituent entities of the Russian Federation. For example, the Unified Medical Information and Analysis System introduced in Moscow contains all types of prescriptions ${ }^{11}$. Beside Moscow, the system was implemented in a number of constituent entities, namely: Moscow Region, Saint Petersburg, Vladimir, Sakhalin, Omsk, Belgorod, and Astrakhan Regions ${ }^{12}$.

As was pointed out earlier, the COVID-19 pandemic is making its amendments in the field of pharmacy prescription regulations. In particular, a new rule came into force in the Russian Federation starting from March 19, 2020. According to this rule, heads of medical institutions should make it possible for the patients to get electronic prescriptions while coronavirus infections continue to spread ${ }^{13}$.

Furthermore, in line with another adopted additional rule, patients with chronic diseases are eligible to receive a prescription with a validity period extended up to three months. This means that patients undergoing regular medical check-up can obtain medications without a necessity to visit an out-patient clinic. In these cases, physicians are recommended to a medical check-up in a remote mode: namely, make regular telephone calls, ask questions about their health condition, and, if necessary, adjust treatment.

Thus, as one can see, prescriptions can be issued in different ways, i.e. via an in-person or remote mode. As far as electronic prescribing is concerned, it should be noted that this practice exists virtually in all EU countries, the USA, and the UK [Bermejo Vicedo T., Delgado Tellez de

${ }^{11}$ Unified Medical Information and Analysis System operates within the framework of the "Information City" Programme approved by Moscow Mayor Sergey Sobyanin in 2011. Available at: https:/www.mos.ru/dit/documents/normativnye-pravovye-akty-gorodamoskvy/view/61220/ (accessed: 23.11.2021)

12 An electronic drug prescription. Available at: https://www.provrach.ru/article/16305elektronnyy-retsept-na-lekarstva-21-m10-12 (accessed: 23.11.2021)

13 Order of the Ministry of Health No 198 n of March 19, 2020 "On temporary procedure for the organization of work of medical organizations for the purpose of implementing measures for prevention and decrease in risks of spread of new coronavirus infection COVID-19”. Available at: http://publication.pravo.gov.ru/Document/View/0001202003190038 (accessed: 24.11.2021) 
Cepeda L., Navarro Cano P., Vázquez Martínez C., Zamarrón Cuesta I., Morejon Bootello E., Balsa Barro J., 2005: 173-181]; [Fry E., Schulte F., 2019]; [Goundrey-Smith S., 2012: 22-41]; [Jolly R., 2011-2012: 1-51] ${ }^{14}$. Notably, the EU has active rules envisioning a functional mechanism for a cross-border exchange of electronic prescriptions. In essence, this mechanism works as follows: a national of Estonia, Finland, Luxembourg, Czech Republic, and Croatia moving from country to country and visiting local pharmacies can refill prescriptions issued in the country of his/her permanent residence. It is planned that by the end of 2021 this system based on EU Directive 2011/24 will unite at least $22 \operatorname{states}^{15}$. Those who design the system are aiming to integrate not only prescription data, but discharge summary information, too. The latter is fairly important since it concerns allergic reactions, therapy received, potential diseases, and previous surgical interventions [Shakel N.V., Ablameiko A.S., 2020:24].

At the same time, analysis of the regional practice of health care workers in the Russian Federation shows that e-document workflow, despite its official introduction, is not used in everyday medical practice. The data transmission system developed in 2017 is not fully functional, since it has not been fine-tuned in an appropriate manner. At the same time, in most cases implementation of the e-document workflow was initiated by the regional authorities ${ }^{16}$.

\section{Legal Grounds for Coding Medicines}

The instructions of the President of the Russian Federation of 4 February 2015 triggered the development of a specialized system for monitoring

${ }^{14}$ Bermejo Vicedo T.,, Delgado Tellez de Cepeda L., Navarro Cano P., Vázquez Martínez C., Zamarrón Cuesta I., Morejon Bootello E., Balsa Barro J. Implantación de un sistema de prescripción electrónica asistida aplicada a la nutrición parenteral en un hospital general // Scielo. 2005, no. 3, pp. 173-181; Fry E., Schulte F. Death by a Thousand Clicks: Where Electronic Health Records Went Wrong // Fortune. 2019. March 18. Available at: https://khn.org/news/death-by-a-thousand-clicks/ (accessed: 24.11.2021); GoundreySmith S. History and Context of Electronic Prescribing in the US and UK. In: Principles of Electronic Prescribing. Chapter 2. Cert Clin Pharm, MRPharmS, SGS Pharma Solutions. Chedworth (UK), 2012, pp. 22-41; Jolly R. The e health revolution - easier said than done // Research paper. 2011-2012. no. 3, pp. 1-51.

${ }_{15}$ Directive of the European Parliament and European Council 2011/24/EU of March 9, 2011 on the application of patients' rights in cross-border healthcare. Available at: https://base.garant.ru/70161772/ (accessed: 25.11.2021)

${ }^{16}$ Gelzin I. What's the arrangement of the system for electronic prescription management? Available at: https://www.kmis.ru/blog/kak-ustroena-sistema-vedeniia-bezbumazhnykh-retseptov (accessed: 25.11.2021) 
the flow of drugs from manufacturers to consumers (via barcoding). It was declared that the main goal of the system is to ensure effective pharmaceutical quality control and combat adulteration of medications.

Several interrelated tasks have to be accomplished to make it possible to effectively implement such a system:

preventing low-quality, adulterated, and counterfeit medications from entering the health market, and possible recall thereof;

prevention of inefficient expenditure, cutting budget spending;

control over targeted flow of medications purchased with public money;

efficient planning, and pharmaceutical stock management at all levels.

It was implied that such a system would be useful for all Russian nationals as well as to members of the business community. In particular, this assumption was substantiated by two reasons. For one thing, consumers get an evident advantage since they are given an opportunity to do a quick check and efficiently verify the legality of the medication they intend to buy.

Secondly, entrepreneurs also benefit from the program. Their potential costs are reduced due to increased efficiency of logistic management. Pharma business also has a lower level of missed profits related to counterfeit and falsified products; pharmaceutical market becomes more competitive, and oriented towards Western healthcare standards [Kudryashova M.N., Sudakova O.A., 2021: 86].

Despite a number of positive developments, the instruction of the President of the Russian Federation was fulfilled with a considerable delay. The necessary legal framework was developed only in 2018-2019.

A number of representatives of the pharmaceutical industry were skeptical about the possibility of effective implementation of the barcoding program in 2020 . They pointed out that production process at the appropriate enterprises has been substantially modified during the coronavirus pandemic, and quite a few employees are put on leave. This led them to the conclusion that the time frame of the program should be extended.

However, the Government did not accept the reasoning of the pharmaceutical industry representatives. In May 2020, it introduced conceptual changes to the Medical Licensing Regulation by supplementing the list of licensing requirements for medical organizations. Since then, entering data on pharmaceutical preparations into the Federal State Information System 
has become a mandatory licensing requirement for medical organizations with a view to facilitate access to pharmaceutical therapy ${ }^{17}$.

In other words, since 1 July 2020 entering data on pharmaceutical preparations into the Federal State Information System has become a mandatory licensing requirement for medical organizations which would greatly facilitate patients' access to pharmaceutical therapy [Taranik M., Savkina A., Dudareva V., 2020: 38].

Thus, coding of medicines is seen as a tool, which would help to create a unified database covering all licensed pharmaceuticals eligible to be sold at pharmacies.

It's quite clear that such a model includes the following sequence of actions: firstly, any national of the Russian Federation receives an electronic prescription; secondly, he/she shows a QR-code at a convenient pharmacy of his choice; thirdly, he/she receives the appropriate medication on the basis of this QR-code; fourthly, at any time and without outside help consumers can check compliance of the obtained product with legal requirements.

\section{Prescription and Non-Prescription Medication Sales}

Analysis of the presented legislative information suggests that federal legislators failed to provide for the possibility to sell prescription medications in a remote mode.

So, Russian citizens have just two options. The first option is to go to a pharmacy to get the necessary medication or ask one of the relatives to do so; secondly, one can apply to a healthcare professional who has not only to issue a prescription medicine, but also (if need be) deliver it to patient's home (the latter rule applies only to persons who are officially under quarantine due an infectious disease dangerous to the public) ${ }^{18}$.

${ }^{17}$ Resolution of the Government of the Russian Federation № 688 of May 15, 2020 “On Amending Article 5 of the Medical Licensing Regulation (except for the aforementioned activities exercised by the medical and other organizations affiliated to a private healthcare system on the territory of the Skolkovo Innovation Center)". Available at: http://publication.pravo.gov.ru/Document/View/0001202005180024 (accessed: 25.11.2021)

18 Order of the Ministry of Health No 198n of March 19, 2020 "On temporary procedure for the organization of work of medical organizations for the purpose of implementing measures for prevention and decrease in risks of spread of new coronavirus infection COVID-19”. Available at: http://publication.pravo.gov.ru/Document/View/0001202003190038 (accessed: 26.11.2021) 
It stands to reason that personal visits to a pharmacy would be the most popular way of getting prescription medications. In such cases, the procedure for dispensing medications is regulated by Order of the Russian Health Ministry No 403 of 11 July 2017 "On adoption of rules for dispensing pharmaceutical preparations for medical use including immunobiological drugs by pharmacies and sole entrepreneurs with a pharmaceutical license". It is set out in this document that prescription medicines can be dispensed only by pharmacies and pharmacy branches as well as sole entrepreneurs (however, the latter are not eligible to sell narcotic drugs and psychotropic substances) $)^{19}$.

Unduly completed prescriptions must be registered in a special logbook. Each entry should contain information about the type of deviation from the rules, full name of the person who issued the prescription, and measures taken by the pharmacist.

Improperly completed prescription is marked with the stamp "Not Valid" and returned to the owner. Each impropriety is reported to the head of the respective medical institution [Romanova A. E., 2019: 123].

Thus, prescription drug sale involves the following important stages:

a physician issues a prescription on the basis of the collected information about the patient's condition;

this prescription is shown to a pharmacist (sometimes, where narcotic drugs or psychotropic substances are involved, a personal identification document should be produced along with the prescription);

the pharmacist closely examines the prescription shown by the customer checking the its correctness and major identifiers, and interprets what is written in Latin);

if the prescription is written correctly, the pharmacist dispenses medication. If the prescription is written improperly, the pharmacist refuses to dispense medication.

Summing up the above, we are witnessing a situation where the possibility of online prescription medicines ordering and delivery is completely discarded.

${ }_{19}$ Order of the Ministry of Health of the Russian Federation No 403 of July 11, 2017 "On adoption of rules for dispensing pharmaceutical preparations for medical use including immunobiological drugs by pharmacies and sole entrepreneurs with a pharmaceutical license". Available at: http://publication.pravo.gov.ru/Document/View/0001201709110035 (accessed: 26.11.2021) 
Sale of non-prescription medications is regulated by several major bylaws setting out the following rules: while selling medications the pharmacist should inform the customer about the main issues related to its use; medications should be stored at the proper temperature, and its shelf life should comply with all regulatory requirements [Streltsov R.S., Gorshkova V.M., 2021: 33].

As far as a remote trade in non-prescription medications is concerned, the major piece of legislation in this field is represented by the Rules for issuing permits for the remote retail sale of medicines for medical use' and delivery of such medicines to citizens. ${ }^{20}$

Remote retail trade in non-prescription medications is conducted by pharmacies having a special license under the stipulation that this license was issued not earlier than a year ago. Furthermore, an eligible retail pharmacy must meet a number of requirements: it should have at least 10 locations on the territory of the Russian Federation where its pharmaceutical activities are conducted; within company premises, it should set up spaces for storing ready-to-ship products; it is also necessary to have a website or a mobile application; one more prerequisite is to have one's own and adequately equipped courier service (e.g. special pharmaceutical containers to ensure safe delivery of temperature-sensitive medicines); availability of the electronic fund transfer system or mobile points of sale [Turchenkova E.S., Kovalenko N.V., 2021: 208].

The Rules for issuing permits for the remote retail sale of medicines for medical use and delivery of such medicines to citizens stipulate that the following information should be made available on the pharmacy's website and mobile application: full company's trade name, Primary State Registration Number (OGRN), Tax Payer Id. Number, addresses, graphic reproduction of the license, graphic reproduction of the permit for remote trade, working hours, full information about the medication ordering service, and enquiry service, information about the medications in stock (as well as the data on the staff member responsible for posting on the Internet all the information about the medication); information concerning medication return issues; data on the authority, which exercises control over

${ }^{20}$ Resolution of the Government of the Russian Federation No 697 of May 16, 2020 "On adoption of the Rules for issuing permits for the remote (distance) retail sale of medicines for medical use, as well as implementation of such trade and delivery of such medicines to citizens, and amending certain acts of the Government of the Russian Federation concerning remote retail trade in medicines for medical use." Available at: http://publication.pravo.gov.ru/Document/View/0001202005180035 (accessed: 26.11.2021) 
retail sales of the medication; and customer's liability [Cherkasova E.S., 2021: 63].

Furthermore, the Rules contain a provision, which stipulates that delivery of the ordered products is performed either by the pharmacy staff or other person on the basis of an agreement specifying the liability of each side, operating procedures, and responsibility. Delivery of temperature-sensitive medications can be done only using temperature controlled vehicles (alternatively, special packaging can be used) [Yatsenko A.M., 2021: 147].

\section{Conclusions}

Currently the legal framework concerning remote trade in medicines in the Russian Federation is far from perfect as evidenced by multiple legal loopholes.

The Parliament lacks supervisory powers. We think that ideally granting the Russian Government the right to organize the system of remote pharmaceutical trade should have been accompanied with vesting supervisory powers in the legislative body. In our view, the Parliament as a representative body is obliged to check how active legal rules are enforced and implemented. Specifically, this responsibility can be devolved to the relevant committee of the State Duma or Federation Council. The absence of supervision, as well as lack of detail in some of the regulations, undermine innovative potential of the online trade.

Advertising on the pharmacy websites. While many foreign countries have legal standards for website design, and requirements concerning marketing of pharmaceuticals on the Internet (e.g. it is not allowed to use colour highlighting of specific prices for medications), in Russia similar rules have not yet been developed. As to the acting Federal Law "On Advertising", it has multiple gaps and inaccuracies. Judging by the current trends in Russian legislative activities, the possibility of adopting foreign experience seems highly unlikely. And this means that for a long time (until the first occurrence of serious and systemic violations) the appropriate regulatory framework will be absent.

Patient-pharmacist interaction. Foreign legislation solves the problem of medication ordering and delivery in the following way: pharmacists as authorized representatives of the respective pharmacies or pharmaceutical networks are eligible to counsel customers on all major relevant issues. Accordingly, delivery of products is performed by pharmacists who bear personal responsibility for the quality of the medications provided. In Rus- 
sia we observe a different situation where clients have virtually no direct contact with persons responsible for quality compliance and timely delivery which hampers the development of online medication delivery services in the Russian Federation.

Thus, the above outlined negative aspects in the field of remote trade in medications in Russia suggest that the existing system can be hardly called efficient.

\section{目 References}

1. Belova O.A. (2021) Topical innovations in the field of remote retail trade. Vestnik Evroaziatskoy Akademii administrativnykh nauk = Courier of the Eurasian Academy of Administrative Sciences, no. 2, pp. 105-107. (In Russ.).

2. Bermejo Vicedo T., Delgado Tellez de Cepeda L., Navarro Cano P., Vázquez Martínez C., Zamarrón Cuesta I., Bootello E., Balsa Barro J. (2005) Implantación de un sistema de prescripción electrónica asistida aplicada a la nutrición parenteral en un hospital general. Scielo, no. 3, pp. $173-181$.

3. Cherkasova E.S. (2021) Transformation of the pharmaceutical market in Russia. Aktualnye problemy i perspektivu razvitia ekonomiki: rossiyskiy I zarubezhnyi opyt $=$ Current issues and development prospects of the economy: Russian and foreign experience, no. 3 (35), pp. 62-67. (In Russ.).

4. Egorova A.V. (2021) Topical aspects of legislation pertaining to remote pharmaceutical sales on the territory of Russian Federation. Sovremennye podhodu $k$ organizatcii snabzhenia lekarstvami=Modern Approaches to Organization of Drug Provision, vol. 8, no. 1, pp. 46-49. (In Russ.).

5. Gorshkova V.M., Streltsov R.S. (2021) Remote pharmaceutical sales as a new trend in the development of the pharma market in Russia. Meditcinsloye pravo = Medical Law, no. 2, pp. 48-51. (In Russ.).

6. Ibragimova L.M. (2021) E-commerce in the pharmaceutical industry. Innovatccii. Obrazovanie. Nauka=Innovations. Education. Science, no. 32, pp. 934-938. (In Russ.).

7. Jolly R. (2012) The e-health revolution - easier said than done. Research paper, no. 3, pp. 1-51.

8. Karonsky E.V. (2021) Modern forms of trade in the pharmaceutical industry. Rossiyskiy ekonomicheskiy vestnik = Russian Economic Bulletin, vol. 4, no. 3, pp. 254-258. (In Russ.). 
9. Krasilnikov E.F., Nikishin A.F. (2019) Online reality of the developments in the Russian pharmaceutical market. Vestnik Altaiskoy Akademii ekonomiki i prava $=$ Courier of the Altai Academy of Economics and Law, no. 2, pp. 217-221. (In Russ.).

10. Kudryashova M.N., Sudakova O.A. (2021) Coding of medications: theoretical and practical aspects. Tverskoy meditcinskiy zhurnal $=$ Tver Medical Journal, no. 1, pp. 84-89. (In Russ.).

11. Kugach V.V., Davidovich E.I. (2017) History of an electronic prescription. Pharma Courier, no. 1, pp. 92-103. (In Russ.).

12. Magomedov A.M. (2020) Development of online trade in pandemic conditions. Menedzhment, ekonomika, politika, sotciology = MEPS: management, economics, politics, sociology, no. 3, pp. 60-65. (In Russ.).

13. Prescribing (2012) UK: Cert Clin Pharm, MRPharmS, SGS Pharma Solutions.Chedworth (UK), pp. 22-41.

14. Romanova A.E. (2019) Remote trade in pharmaceuticals as a possible novelty in the Russian legislation. Vestnik Nizhegorodskogo gosudarstvennogo universiteta $=$ Courier of State University of Nizhny Novgorod, no. 3, pp. 120-124. (In Russ.).

15. Shakel N.V., Abramenko A.C. (2020) Foreign experience in implementing electronic healthcare systems: critical analysis. Zhurnal mezhdunarodnogo prava i mezhdunarodnykh otnosheniy = Journal of International Law and International Relations, no. 92-93, pp. 20-26. (In Russ.).

16. Streltsov R.S., Gorshkova V.M. (2021) Problems and perspectives of online trade in medications on the pharmaceutical market of the Russian Federation. Nauka Krasnoyarya = Science of Krasnoyarye, vol. 10, no. 4, pp. 30-34. (In Russ.).

17. Taranik M., Savkina A., Dudareva V. (2020) How to start working with medications within the "Coding" information system. Kachestvo upravlenia $v$ zdravookhranenii $=$ Quality Management in Healthcare, no. 3, pp. 37-39. (In Russ.).

18. Turchenkova E.S., Kovalenko N.V. (2021) Online pharmacy as a new form of medication sales. Biznes. Obrazovanie. Pravo $=$ Business. Education. Law, no. 1 (54), pp. 204-210. (In Russ.).

19. Yatsenko A.M. (2021) Regulatory issues of remote drug sales. Uchenye zapiski tambovskogo filiala rossiyskogo obedinenia molodukh uchenukh=Scholarly notes of the Tambov Branch of the Russian Union of Young Scientists, no. 22, pp. 143-150. (In Russ.). 
Information about the authors:
A.S. Kornienko - Candidate of Sciences (Economics), Assistant Professor.
N.G. Neretina - Candidate of Sciences (Sociology), Assistant Professor.

The article was submitted 22.09.2021; approved after reviewing 12.11.2021; accepted for publication 26.11.2021. 